This PDF is a simplified version of the original article published in Internet Archaeology. Enlarged images, and interactive features which support this publication can be found in the original version online. All links also go to the online version.

\title{
Making the Case for the Public Benefits of Development-led Archaeology
}

\author{
Barney Sloane
}

\section{Summary}

This paper provides an update on progress of the EAC Working Group for public benefit from development led archaeology, giving the background to the concept as well as outlining why the EAC is developing guidance for establishing public benefit. Understanding that there are many stakeholders all of whom have their own values and priorities will be key. An online resource with case studies showcasing public benefit is under production. This article is an adaptation of Sloane (2020).

\section{Introduction}

The European Archaeological Council action plan - the Amersfoort Agenda - was published in 2015 (Schut et al. 2015). Following this action plan, the EAC Board embraced the objective of 'Daring to Choose' (Theme 2). Participants in this theme established three key recommendations that would underpin a sustainable and successful approach to archaeology (Figure 1). In our work on making choices in heritage management (Sloane 2018), a survey of member states revealed that there was a widespread wish for support in explaining the public benefits that were created by development-led archaeology (also known as 'preventive archaeology' or sometimes 'rescue archaeology') to policy-makers, developers, archaeologists and the wider public. This desire to be clear about public benefit stemmed from two key drivers: (i) a genuine desire to increase public engagement with archaeology and (ii) an unease that there is a growing - if misguided - perception that development-led archaeology can be an unwelcome financial burden incapable of creating much public value. The Board of the EAC therefore determined, through the establishment of a Working Group, to provide much clearer evidence of the benefits that can be derived from development-led archaeology and thus work towards a means to identify and capture its wider public value. The Working Group was further supported by the European Archaeological Association as part of our drive to work more closely together. 


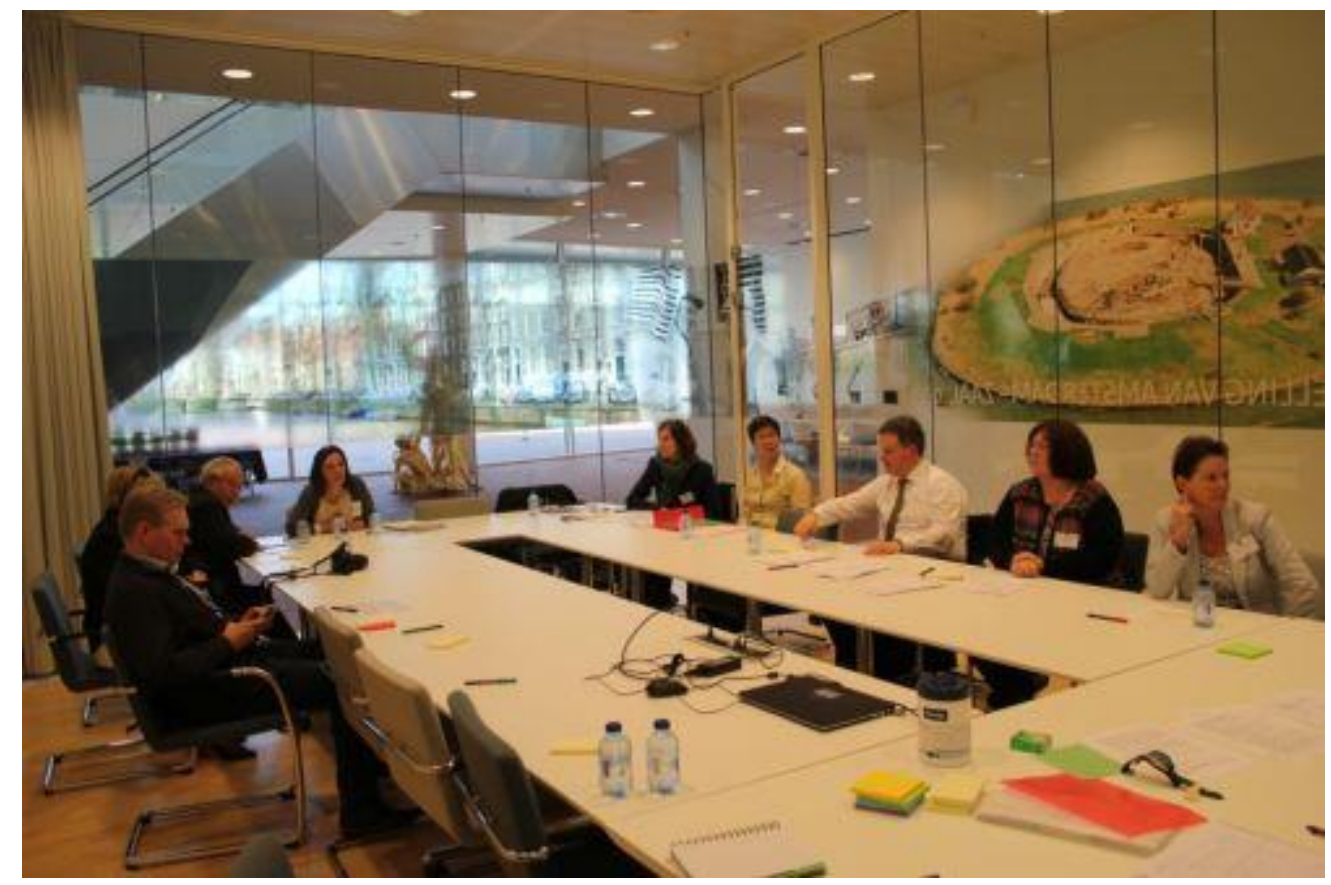

Figure 1: Round table discussions at the 15th EAC symposium in Amersfoot, 2014

This ambition was given further focus through the decision of the EAC Board to endorse a project funded by UK Research and Innovation, the coordinator of the Research Councils of the United Kingdom. The four-year project Measuring, maximising and transforming public benefit from UK Government infrastructure investment in archaeology, led by Dr Sadie Watson of Museum of London Archaeology, seemed to the EAC to be focusing precisely where the Amersfoort Agenda action plan had recommended and to have relevance far beyond UK borders. The author (BS) was included as a Co-Investigator on the project and Dr Watson was invited to act as scientific coordinator for the Prague symposium leading to this publication (Figure 2). This short article sets out the framework within which the Working Group is progressing.

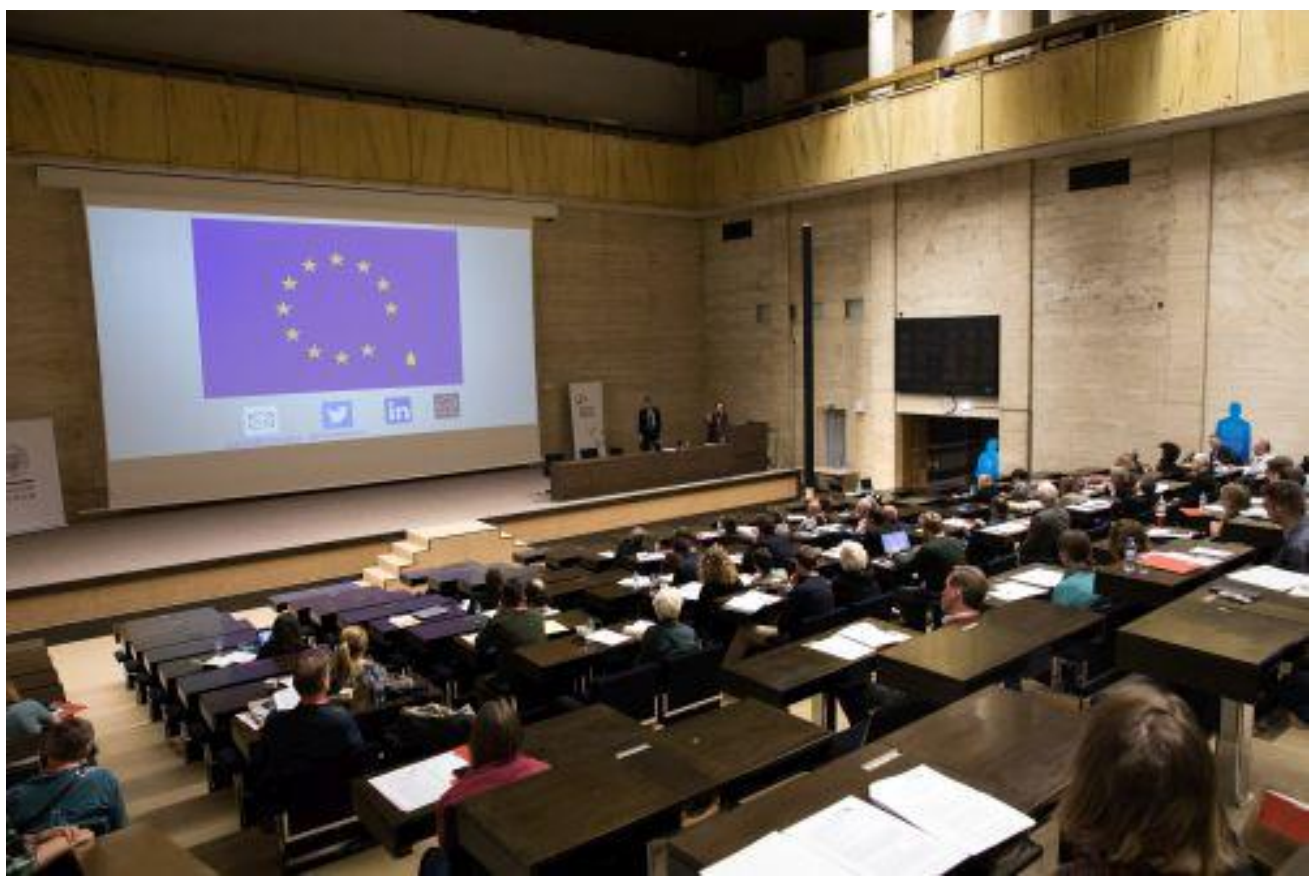


Figure 2: : Barney Sloane (EAC President) and Sadie Watson (Scientific Convenor at the 21st EAC symposium in Prague, 2020

The 1954 European Cultural Heritage Convention (the 'Paris Convention') was arguably the first pan-European expression of the acknowledgement that culture is a unifying force, that mutual understanding of different 'peoples' was a key to creating the appreciation of culture, and that fostering the study of the 'history and civilisation' of the member states was a means to create the necessary understanding. While archaeology was not specifically mentioned, cultural objects were. Here lay the seeds of an understanding that archaeology as a discipline could create profound public value far beyond the academic exploration that had characterised its practice in the decades before. The 1969 European Convention on the Protection of the Archaeological Heritage (the 'London Convention') developed this notion specifically, seeing the objective of the proper management of archaeological sites and their excavation as contributing to 'scientific, cultural and educational' activities, and generating 'historical and cultural value'. The 1992 Valletta revision of the London Convention established the need for archaeological heritage management to be built into wider state planning policies and to be appropriately resourced and funded, while also identifying archaeology as 'a source of the European collective memory and as an instrument for historical and scientific study'. These three conventions thus directly connected the fostering of unity in the European community with the appropriate management of archaeology in the context of land development and state planning procedures.

Primarily as a result of the ratification and adoption of these conventions, and of the consequent improvement of archaeological heritage management across Europe, the scale and intensity of archaeological investigation has grown very considerably over the last 30 years. The investment, whether state or private, has risen to support this. In the UK, for example, it is estimated that the commercial archaeological market in 2018 was worth up to $£ 238 \mathrm{~m}$ (Landward Research 2019, S. 4), generated by some 6000 archaeologists on upwards of 5000 investigations. The contribution that such investment has made to our understanding of the past cannot be denied and, crucially, is increasingly recognised both by archaeologists and by the developers who have funded the work (see for example in England).

However, there is a considerable risk that a didactic, top-down dissemination of the products of this considerable investment, often to a limited specialist audience, is going to miss its target and fail to prove its public value in the way envisioned in the Faro convention and a number of other charters and conventions pertaining to cultural heritage. (The context of and need for development of authentic public value is artfully explored in Olivier 2020.) If we can eliminate this risk and create a new way of operationalising public value, a great prize lies within reach, where the regular and authentic involvement of the public in decision-making about their heritage is matched by a widespread, shared enjoyment of the value delivered from those decisions and people can see the direct value of their participation.

\section{Public Benefits and Public Value}

Creating the conditions for such a paradigm shift in public involvement will not be straightforward, however. While there is a very considerable international body of research focused on archaeology and public value, and university departments focusing 
on the transformation of development-led archaeology are emerging, there are few specific proposals on how to tackle the transformation of practice and management of development-led archaeology in order to create the conditions necessary for the shift. To create such conditions, we believe that it is vital to capture the full range of particular and tangible public benefits of archaeology. Developing a shared understanding of these benefits, we argue, sets the stage for anticipating them within the mechanisms and processes that govern development-led archaeology, and, where they materialise, the means of sharing the recognition of successes with stakeholders. If this approach is authentic and avoids the trap of being top-down or just paying lip-service, different constituencies should increasingly see themselves as owning those benefits as they accrue, and thus come to value their continuing interaction with the processes that create them. The emergence of such shared value will, we hope, drive further investment of thought and creativity into the processes to enhance the benefits, thus in turn steadily growing that value.

\section{Exploring the Range of Benefits}

It is axiomatic that we support and undertake archaeological research to further our understanding of the past. But such increased knowledge only takes us part of the way toward meeting the goals envisaged in the three conventions noted above. To establish a lasting and deep-rooted public value, we need to think more carefully about how we can define other benefits that development-led archaeology can bring and about how we might make the realisation of the maximum range of benefits part of the planning of each and every future investigation. So what are these benefits? Past and current debates on this provide a helpful framework on which to build.

\subsection{Archaeological commodities}

Gabriel Moshenska (2009) considered archaeological benefits within an economic framework, viewing them as 'commodities'. He posited that 'commodities' - things possessing value - exist in a variety of forms, but could be grouped into a small number of distinct types.

i. Archaeological materials. This encompasses the material outputs of archaeological research, including both objects and sites.

ii. Archaeological knowledge and skills. This comprises knowledge gained by fieldwork or research, and the skills needed to do the work.

iii. Archaeological work. The forms of work carried out by archaeologists, for which (in development-led archaeology) they are normally paid.

iv. Archaeological experiences. People's encounters with archaeological processes and products such as visits to museums or archaeological sites, educational courses and similar.

v. Archaeological images. The recognisable archaeological themes and images that feature in popular culture representations of the past; in advertising, architecture, film, art and elsewhere - a theme explored in depth in Holtorf 2007.

Neil Gestrich (2011) warned against thinking of archaeology as a purely saleable commodity, recalling the more fundamental fact that 'laws governing the protection of archaeological remains were not created in order to provide a market for the commodity of archaeological skills. They were created in recognition of the fact that ... there lies a 
debate about the past which shapes our identity today. It is this debate that is the actual objective of archaeology, and it is also the reason why people value the commodities that result from it'. Response to this warning led to a focus on the values in archaeological commodities, identifying a number of forms useful to our framework, including: monetary, cultural, intellectual, social and emotional (Moshenska and Burtenshaw 2011). Moshenska and Burtenshaw also reiterated the principle of archaeology as a public good not a traded commodity, and the need to establish how archaeology contributes to wellbeing and quality of life. They concluded that 'the strength of any model of archaeological value lies in its ability to communicate the roundest possible view of the benefits that archaeology offers' (2011, 84), a point central to our approach.

\subsection{Instrumental benefits of archaeology}

Others had earlier begun to specify particular instrumental or outcomes-based benefits from archaeology that could help us to flesh out an emerging model for our work. In the US, Minnis et al. $(\underline{2006}, 17)$ asked a specific hypothetical question of US archaeology: 'So,' the Skeptic asks, 'you expect me to pay taxes so you can play in the dirt digging up old stuff instead of me saving more for my kid's education or for producing more vaccines against childhood illnesses in the Third World?' In crafting a response, they recognised the following tangible benefits of archaeology:

i. Counteracting racism. In the US archaeology has become an important tool for discovering and teaching African-American history and for initiating dialogue about the continuing effects of racism.

ii. Documenting accomplishments of ignored communities.

iii. Providing time-depth as a response to short-termism of the modern age. A longterm perspective is worth investing in because it changes public dialogue when the benefits and costs of policy decisions are considered over time periods exceeding a single human generation.

iv. Contribution to human ecology. Understanding ecological dynamics for environmental conservation purposes, documenting novel uses of plant resources, understanding strategies for farming marginal lands, expanding increasingly impoverished inventory of crops to combat food shortages.

v. Independent evidence base. Detailed knowledge of the past drawn from archaeology can challenge myths, misconceptions, and stereotypes.

vi. Historic context development. Archaeology can assist planning and environmental compliance, and thereby make (for example) mining more efficient and hence profitable for the state.

vii. Tourism: wide popular support, as evidenced by book sales, television ratings, and visitations at publicly supported sites and museums.

These reflections, both 'commodity-based' and instrumental benefits, raise the matter of 'customers' or beneficiaries for them. The good conduct of development-led archaeology offers potentially different benefits to stakeholders - to the investors paying for the work, to the policy-makers and ministers responsible for the framework of archaeological heritage management, to scientists and policy-makers in ostensibly non-heritage domains, to the archaeologists themselves, and to the wider public. What is perceived as a benefit for one constituency may be seen as of limited interest by another, and any framework for realising the full range of benefits would need to recognise this fact. 


\section{Towards a Framework for Understanding the Public Benefits of Development-led Archaeology}

With these insights we aim to develop a framework that addresses the ethical responsibility to deliver the public good of development-led archaeology, articulates the benefits that can be realised through its practice using real case studies, and offers clear evidence of the economic value and desirability of maintaining coherent and robust policies in its support.

Our first pillar is an ethical one. We will reiterate the reasons behind the existence of state laws protecting archaeology, and their alignment with the European conventions that have helped shape archaeological heritage management. This reminds our target audiences that the objective was to realise culture as a unifying force and an instrument for mutual understanding.

Our second pillar is an economic one. We will demonstrate the financial impact of conducting development-led archaeology by revealing the evidence of the very low economic cost to taxpayers and investors. Our approach will be to evidence the total cost of development-led archaeology against the total size of the construction industry in each state. Current pan-European modelling over a sample of 21 states suggests a cost of less $0.1 \%$ of construction industry turnover, with variations depending on individual state approaches.

Our third pillar is clear proof of concept. We will provide genuine case studies of the delivery of public benefits through development-led archaeology under a number of headings that will be understandable to our stakeholders. These headings are summarised as follows:

i. Contribution to a shared history. This is the most fundamental and obvious benefit to society and is enshrined in Valletta (and every other convention on archaeological heritage). Archaeology offers a different scale of history, bringing in a human dimension understandable by all. A requirement for an investment in investigation which has a clearly articulated knowledge 'dividend' will be more readily understood.

ii. Artistic and cultural treasures. The most frequent archaeological stories in the media, and the most often-asked questions by members of the public revolve around the unearthing of wonderful cultural objects. Such finds can draw international interest to a site and attract an investor and can, occasionally, act as dramatic catalysts for inward economic investment to an area.

iii. Local values. People often express pride or value in the archaeology on their doorsteps, even if that archaeology may not be so important as to make the national media headlines. An investigation that is alive to this local pride is one that may help the investor or developer engage local support.

iv. Place-making and social cohesion. Archaeology has powerful messages to send about the changeability of societies over time, about the mobility of people, and about the ways in which cultural values can be adopted and shared to create better places to live. Such stories shared as part of investigations can provide a 
catalyst for understanding and new community perspectives. The physical remains can be used as blueprints or assets for redevelopment of locales to the joint benefit of commerce and public alike.

v. Educational benefits. Linked to the above, but wider in impact, this recognises that archaeology can generate specific educational benefits. For example, certain kinds of archaeological site may shed light on past adaptation to climate change. While these rarely provide practical answers to the issues facing 21 st-century Europe, they can be remarkable educational tools. Suitably planned investigations can feed such information to school children and colleges.

vi. Contribution to science and innovation. An overlooked benefit of investment in archaeological investigation is the impact on wider scientific research. For example, the recovery of ancient plant remains can provide very important information about past species and variants (and even, on occasion, viable seeds); ancient DNA techniques have permitted the study of epidemics; and recovery of human skeletal remains have informed our understanding of the causes and effects of disease.

vii. Health and wellbeing. The practice of archaeology can itself be used for helping people who are suffering from a range of conditions. Examples from the UK include the Operation Nightingale project

viii. Added economic value to developers. Direct economic benefit to the investor is possible in a development that takes account of the archaeological dimension of the project. 'There are considerable benefits to clients from a carefully considered and executed archaeological programme which can be used to boost public relations and leave a legacy to society through increase in knowledge, providing a pride of place for local communities' (written by a consultancy advising developers).

EAC will provide an online resource that will include case studies for each of these different categories of tangible benefit, with an assessment of how the benefit was realised. That in turn will allow us to create the framework for understanding how the capability to create similar benefits in future projects can be built into the processes and mechanisms for archaeological heritage management.

In creating that framework, we hope to ensure a stable basis for archaeology upon which it may then be possible to build a far richer interaction or dialogue between the public and their heritage. Such an interaction will go far deeper than common current and often one-way approaches, such as offering site visits or viewing galleries, websites or school trips. We envisage a process where expert and community views combine to shape our understanding of significance, where the public have a role in decision making, where citizen science helps shape research frameworks, and where dissemination of findings is targeted to the local communities as well as the experts. From this, we all might realise the full public value of our shared archaeological heritage.

If we are successful, we may be able to help reverse scepticism, and allow archaeology to play 'a significant role in struggles, for and against the rights to self- determination and participation in public affairs; freedom from discrimination; life and freedom from persecution; education; belief, association, assembly and expression; work and just conditions of work; the highest attainable physical and mental health and an adequate standard of living; and conservation of, access to and participation in science and culture' (Hardy 2017, 106). In doing so, we may be able to meet a good number of the objectives enshrined in the European conventions on cultural heritage first envisioned more than half a century ago. 


\section{Bibliography}

Council of Europe 1992 European Convention on the Protection of the Archaeological Heritage (Revised), Valletta, 16 January 1992. Council of Europe Treaty Series 143. https://www.coe.int/en/web/conventions/full-list//conventions/rms/090000168007bd25

Gestrich, N. 2011 'Putting a price on the past: the ethics and economics of archaeology in the marketplace. A reply to "What is Public Archaeology"', Present Pasts 3(2). http://doi.org/10.5334/pp.50

Hardy, S. 2017 'The archaeological profession and human rights' in G. Moshenska (ed) Key Concepts in Public Archaeology, London. 93-

106. https://doi.org/10.14324/111.9781911576419

Holtorf, C. 2007 Archaeology is a Brand! The meaning of Archaeology in Contemporary Popular Culture, London and New York.

Landward Research Ltd. 2019 State of the Archaeological Market 2018, https://landward.eu/wp-content/uploads/2019/03/Archaeological-Market-Survey2017-18.pdf

Minnis, P.E., Kelly, D.S., Sebastian, L., Ingram, S.E. and Spielmann, K.A. 2006 'Answering the skeptic's question', The Society for American Archaeology Archaeological Record 6(5), 17.

Moshenska, G. 2009 'What is public archaeology?', Present Pasts 1, 4648. http://doi.org/10.5334/pp.7

Moshenska, G. and Burtenshaw, P. 2011 'Commodity forms and levels of value in archaeology: a response to Gestrich', Present Pasts 3(2), 83-

84. https://doi.org/10.5334/pp.51

Olivier, A. 2020 'Socialising heritage: policy and praxis', Österreichische Zeitschrift für Kunst und Denkmalpflege LXXIV, 105-18.

Schut, P.A.C., Scharff, D. and de Wit, L.C. 2015 'Amersfoort Agenda' in P.A.C. Schut, D. Scharff and L.C. de Wit (eds) Setting the Agenda: Giving New Meaning to the European Archaeological Heritage, EAC Occasional Paper 10, Namur: Europae Archaeologiae Consilium. 15-23. https://www.europae-archaeologiae-consilium.org/eac-occasionalpapers

Sloane, B., 2018 'Making choices: Valletta, development, archaeology and society', Internet Archaeology 49. https://doi.org/10.11141/ia.49.3

Sloane, B. 2020 'Broadening understanding of the public benefits of development-led archaeology', Österreichische Zeitschrift für Kunst und Denkmalpflege LXXIV, 119-22. 